"Village banks: a financial strategy for developing the South African poor households"

\begin{tabular}{|c|c|}
\hline AUTHORS & $\begin{array}{l}\text { Polly Mashigo } \\
\text { Humayun Kabir }\end{array}$ \\
\hline ARTICLE INFO & $\begin{array}{l}\text { Polly Mashigo and Humayun Kabir (2016). Village banks: a financial strategy for } \\
\text { developing the South African poor households. Banks and Bank Systems, 11(2), } \\
\text { 8-13. doi:10.21511/bbs.11(2).2016.01 }\end{array}$ \\
\hline DOI & http://dx.doi.org/10.21511/bbs.11(2).2016.01 \\
\hline RELEASED ON & Saturday, 02 July 2016 \\
\hline JOURNAL & "Banks and Bank Systems" \\
\hline FOUNDER & LLC "Consulting Publishing Company "Business Perspectives" \\
\hline & $\begin{array}{l}\text { ニz: } \\
\text { = }\end{array}$ \\
\hline NUMBER OF REFERENCES & NUMBER OF FIGURES \\
\hline 0 & 0 \\
\hline
\end{tabular}

(C) The author(s) 2023. This publication is an open access article. 
Polly Mashigo (South Africa), Humayun Kabir (South Africa)

\title{
Village banks: a financial strategy for developing the South African poor households
}

\begin{abstract}
Access to financial services is a vital component of poverty alleviation, community and individual development. The major constraint experienced by poor South African households is lack of financial support emanating from systemic weaknesses of the formal financial institutions which include lack of infrastructural facilities, high transaction costs and traditional collateral. The objective of this study is to propose a financial strategy that would improve access to financial services and develop the poor households in South Africa. The research is literature-based since it draws on a wide range of academic literature that documents village/community banks and financing the poor. International best practices which are equally important and crucial are used to identify financial inclusion strategy that alleviates the need for collateral and high transaction costs in financial transactions. The study reveals that village banks create access to basic financial services to the poor households on a sustainable basis through community/village mutual trust, relationships, accountability, perfect knowledge, customs and participation. Based on these findings, it is recommended that village banks be established and supported adequately and used as a financial inclusion strategy for developing the poor households in South Africa.
\end{abstract}

Keywords: village bank, community bank, poor households, South Africa. JEL Classification: B21, D02, D04, R51.

\section{Introduction}

Village banks are formed for improving social inclusion and poverty alleviation. Village banking initiative greatly contributes towards reduction in poverty, particularly, it empowers poor women and encourages social and economic development in poor communities. The facilitation and coordination of the provision of financial services is a vital component of poverty alleviation, community and individual development as well as harnessing the potential of the poor households (Greene and Berroth, 2002). There is and has always been a strong demand or need for financial services such as savings, low-cost credit/loans, transmission and insurance by the poor households in South Africa, as also emphasized by the Banking Council 1999 (Mathie, 2001). However, the provision of these financial services by the formal financial institutions, both conventional banks and microlenders, is dominated and constrained by institutions' systemic weaknesses, high transaction costs, the need for traditional collateral, as well as low returns and infrastructural limitation (Mashigo and Schoeman, 2011; Nigrini, 2001; Department of Agriculture, Forestry and Fisheries, 2009). This information is used by these institutions to assess the probability that the household would default on (loan) payments and whether a household is considered a low or high risk borrower (Song, 2002). Since the poor household does not possess valuable assets or collateral to secure

(c) Polly Mashigo, Humayun Kabir, 2016.

Polly Mashigo, Assistant Dean Teaching and Learning, Faculty of Economics and Finance, Ga-Rankuwa Campus, Tshwane University of Technology, South Africa.

Humayun Kabir, Lecturer, Tshwane University of Technology, South Africa. credit, the formal financial institutions, according to Meagher and Wilkinson (2001), hesitate to lend to this kind of households whose repayment capacities seem uncertain and risky. The poor households, therefore, become uncertain about future prospects and are unable to smooth consumption, meet dayto-day expenses, and mitigate the effects of financial, social and economic unforeseen circumstances. This may, in the long run, amplify the poverty cycle. Business Day (2010) reported that nearly 20 million of South Africans have either a savings or a transaction account, and 10.2 million have never banked. Even the Mzansi, a low-cost national savings account, which was introduced in 2004 to cater for 13.2 million South Africans who did not have bank accounts, was not a suitable vehicle for financial inclusion, since the account could not resolve the contradiction between affordability and access (Hawkins, 2004; Napier 2004; Mashigo, 2007). It is therefore important to consider matching savings with expansion of credit products. Microfinance in South Africa and developing world is widely advocated as an alternative to formal banking and a powerful tool to reduce poverty, vulnerability or unforeseen/unexpected crisis and improve social inclusion. However, how best to achieve these outcomes remains a challenge, hence, to date, microfinance continues to be the subject of considerable debate.

The provision of financial services is severely lacking in the poor communities in South Africa and this hinders the development of the poor households. The major obstacles to lack of financial support emanate from systemic weaknesses of the formal financial institutions which include high transaction costs, traditional collateral, and most importantly, lack of infrastructural facilities and repeated 
regulatory reforms. Hence, the study poses the research question: what are the issues that hinder access to financial services by the poor households in South Africa? Consequently, the study aims to propose a financial strategy of a financial institution (i.e., village bank) that would provide low-cost credit, savings and insurance needs of the poor households which is crucial to their development, sustainning their livelihoods and improving their living standards, in general. The study will help us in understanding the financial strategy of a village banking initiative for developing poor households in South Africa. Furthermore, there has been relatively limited academic research on village banks in an African context, especially in the South African context. Thus, this study will fill the gap in the relevant literature.

\section{Research methodology}

In addition to a wide range of literature that documents village banks and access to financial services by the poor households, the article espouses a qualitative method and uses a desktop study. Content analysis is used to analyze secondary data. Multiple sources of data such as journal articles, books, official documents, annual reports, newspaper articles and internet blogs are used to identify patterns and themes and analyze commonalties or disparities and challenges experienced by the poor households in accessing finance for their development and sustaining livelihoods. Secondary data provide the researchers with a scope to analyze high quantities of data gathered in a thematic way. International best practices which are equally important and crucial are also used to identify financial strategies that support the poor households and alleviate the need for traditional collateral, decrease transaction and information costs.

In the next section, this study discusses relevant literature. Here, the study briefly discusses the concept of a village bank, provides an overview of village banks in South Africa including the regulation and international experience regarding community/village banks in other countries.

\section{Literature review}

2.1. Village banks. Village banks, also known as community banks, are generally self-help institutions that are rotating saving and credit association (stokvels), which subsequently, facilitates the creation of social capital and accumulation of saving mobilization with low transaction costs. Historically, village banks were conceived to be either shareholding companies limited by shares or guarantees and have a profit motive that would result in higher dividends paid to members (Nigrini, 2001), or cooperatives with easy cancellation of shares, greater flexibility in the voting rights, lower registration costs, and intermediation of savings. Cooperatives were, therefore, established to operate in rural areas for poor communities to have better access to financial services.

Jones and Dallimore (2009) define village banks as semi-formal and self-sustaining financial institutions which create access to basic banking services to community/village members on a sustainable basis. The provision of these services is done by utilizing community's relationships, rules, customs, knowledge, and resources. Village banks are owned, financed and managed by the community members themselves who would be shareholders. This shareholding, according to Nigrini (2001), allows for easy entry for new members and qualifies each member to vote for a board of management responsible for, amongst other things, approving loans, appointing an administrator, setting fees and compiling the annual accounts. These banks do not receive any finance from any institution, but are solely financed by the community and responsible for providing appropriate financial services such as deposit/savings, credit and other related services to their members. Village banks would reduce information costs, remove the need for collateral, decrease transaction costs of savings mobilization (Department of Agriculture, Forestry and Fisheries, 2009). The savings of members are mobilized by village banks and deposited by the banks at a commercial bank. Members of the village banks may receive credit (micro loan) from their banks once their savings are mobilized by the banks for a while. The staff member of the village banks receives incentives from the village banks for marketing the concept of their respective village banks (Coetzee and Cross, 2003).

2.2. Village banks in South Africa. Village banks in South Africa are registered as Financial Service Cooperatives (FSCs) (Satgar, 2003; Nigrini, 2001) which are perceived to be a more suitable structure to operate in rural areas. In South Africa, village banks were founded in 1994 by the International Fund for Agricultural Development (IFAD) and influenced by the South African cooperative movement, focusing on agriculture and farming activities through the Department of Agriculture (Satgar, 2003; Nigrini, 2001). Following the Financial Sector Summit held in 2002, constituencies of the National Economic Development and Labor Council (Nedlac), business, government, labor and community, orchestrated the shift from agriculture and farming only to incorporate efficient delivery of financial services to the poor and small and micro enterprises. The responsibility for cooperatives was, then, transferred to the Department of Trade and Industry with the purpose of enhancing national savings and access to finance (Cooperative Banks 
Development Agency and South African Reserve Bank, 2010/11). Village/community banks in South Africa are affiliated with Financial Services Association (FSA) (Satgar, 2003). The FSA regulates FSCs as promulgated by the Cooperatives Act 14 of 2005 and offers a centralized support structure for the FSCs (Cooperative Banks Development Agency and South African Reserve Bank, 2010/11). The Act allows informal member-based groups to pool funds and utilize such funds for the benefit of their members through a common bond that exists between members within the group.

Village banks in South Africa exist in many areas such as Alberton, Lydenburg, Mafikeng, Lichtenburg and others. It should be noted that village banks in South Africa are sometimes referred to as "Cooperative Village Banks". The following village banks (Cooperative Village Banks) have been formed in South Africa:

- Lehurutshe (formed in 1999).

- Lothlakane (formed in 1995).

- Motswedi (formed in 1996).

- Kraaipan (formed in 1994).

Source: Satgar (2003, p. 10).

It is worthy of note that, besides the village banks operating in South Africa, there are a number of FSCs banks (refer to Table 1) operating in the country in order to finance the poor households. They assist rural communities, provide financial services, motivate clients for saving for future use, and offer micro-credit to rural entrepreneurs, particularly, who did not receive financial support from commercial banks.

Table 1. Financial service cooperatives banks in South Africa

\begin{tabular}{|l|l|}
\hline Alrode SACCO Ltd & (Established in 1996) \\
\hline $\begin{array}{l}\text { Beehive Savings \& Credit Co- } \\
\text { operative }\end{array}$ & (Established in 2002) \\
\hline $\begin{array}{l}\text { Disaneng Financial Service Co- } \\
\text { operative }\end{array}$ & (Established in 2000) \\
\hline Ditsobotla SACCO & (Established in 2000) \\
\hline $\begin{array}{l}\text { Mathabatha Financial Services } \\
\text { Primary Cooperative }\end{array}$ & (Established in 2000) \\
\hline Motswedi FSC & (Established in 1996) \\
\hline Nehawu SACCO Limited & (Established in 2006) \\
\hline Samwu SACCO Ltd & (Established in 2001) \\
\hline Sibanye Cape SACCO Ltd & (Established in 1997) \\
\hline $\begin{array}{l}\text { Stellenbosch Wine-Lands \& Em- } \\
\text { ployees (SWE) Savings \& Credit } \\
\text { Cooperative Ltd }\end{array}$ & (Established in 2002) \\
\hline
\end{tabular}

Source: Calvin and Coetzee (2010, pp. 12-32).

2.3. Cooperatives legislation in South Africa. In South Africa, all savings and credit unions are formed under an organization called South African Credit Cooperatives League (SACCOL) (Satgar,
2003). SACCOL is an umbrella body that provides training and other support to its affiliated savings and credit unions. The cooperative credit unions [i.e. Savings and Credit Cooperatives (SACCOs) and village-based financial services cooperatives] are operated through exemptions from the Banks Act of 1990 (Satgar, 2003) and regulated under the following legislation:

- Cooperative Act of 1981/Cooperative Act of 2005.

- Cooperative Bank Bill, 2004.

- Cooperative Banks Act of 2007.

\section{International experience: village banks/ community banks and credit unions in other countries}

The first cooperative bank (i.e., Raiffeisen Bank) was formed in Germany in 1864 in order to establish and promote the perception of "self-help" in rural areas by providing savings and credit services (Nigrini, 2001, p. 5). Subsequently, the cooperative banks played a significant role in pursuing economic sustainability and social responsibility and lead to the formation of micro-finance institution such as village banks, community banks, and other forms of micro-lending institutions across the globe. As a result, according to World Council of Credit Unions, there are about 53,000 cooperative credit unions operating in 100 countries till 2011, serving over $7.5 \%$ of the world population (The Connection, 2011, p. 9).

Village/community banks operate through solidarity group lending and savings. Village/community banking models in countries like India, Nigeria, Tanzania, Malawi, Indonesia, Spain, Ghana, Canada and Bangladesh are found to be successful in tackling collateral problems, high risk, high transaction/security costs and low returns. Along with South Africa, since 1994, village banks have also been established in many other African countries such as Benin, the Congo-Brazzaville, Gabon, Guinea, Mauritania, Uganda and Kenya (Nigrini, 2001).

Considering the Bangladesh experience, different types of micro-financing programmes have been adopted by a number of organizations in Bangladesh for many years in order to support the poor. As a result, the Grameen Bank (a micro-financing institution based in Bangladesh) together with $\mathrm{Dr} \mathrm{Mu}-$ hammad Yunus received the Nobel Peace Award 2006 "for their contribution towards poverty reduction through micro-financing" (Mahmuda et al., 2011, p. 3). Grameen Bank was established in 1974 in Bangladesh. After 35 years (i.e., 2009), the bank reached 7.52 million poor borrowers and covered all areas in Bangladesh (MRA, 2008). The objectives of the Grameen Bank are: 
- to extend banking facilities to the poor;

- to eliminate exploitation by money lenders;

- to create small enterprise opportunities for the unemployed and underemployed;

- to bring disadvantaged people within the fold of some organizational format which they can understand and operate and can find some sociopolitical and economic strength through mutual support;

- to reverse the age old (poverty) cycle of "low income, credit, more income, more credit, more investment, more income" (Holcombe, 1995).

In Malawi, thousands of poor women achieve economic gains and become economically independent (Mhango, 2015; Masina, 2013). For instance, since 2010 to 2013, more than 5000 Malawian women from 81 villages have economically benefitted through a village banking programme called "Village Savings and Loans" run by a Malawian organization known as Center for Alternatives for Victimized Women and Children (Masina, 2013, p. 1).

\section{Findings and discussions}

In South Africa, the first Cooperative called "Consumers' Cooperative" was formed in 1892 (Nigrini, 2001, p. 4). The Consumers' Cooperative was not registered under the Cooperative Act due to the fact that no Cooperative Act was assigned in the regulations at that time in South Africa; the Consumers' Cooperative was formed in terms of the Companies Act. During 1989, the concept of village banks in South Africa was formulated in "The Village Bank Module" developed by John and Marguerite (Nigrini, 2001; Holt, 1994). In 1994, the village banks have been introduced in South Africa and their operations started slowly since then (Satgar, 2003; Nigrini, 2001). Subsequently, South African village banks received financial and other support from World Bank Funding and other international donor funding (www.rurdev.usda.gov, 2012).

However, it becomes crucial to start identifying the financial potential, skills and capacity that the South African poor communities possess in an effort to meet their financial needs and help them to develop and sustain their livelihoods. The first point of departure is to establish effective and sustainable financial institutions in the form of village banks, the self-help institutions as financial inclusion strategy for developing the poor households and addressing poverty issues. Although "these institutions (the village banks) are by nature savings-first institutions, and experience shows that quick growth could lead to formation of a weak institutional and collective base" (Coetzee and Cross, 2003, p. 1), to rationalize the possible use of village banks as a channel of providing poor households access to much- needed cash, credit or savings which are bound under social contract, becomes imperative. Theoretical financial strategies, models or mechanisms in countries like Bangladesh, Indonesia, Ghana and Kenya embrace group lending as a possible alternative for lenders to overcome information asymmetries, collateral constraints and high transaction costs and also a mechanism to provide credit and savings to the poor households.

The study reveals that access to financial services, cash, credit, and insurance schemes is central to economic life. Because of its peculiar nature, cash is needed for day-to-day consumption and plays an indispensable precautionary role in the smoothing of consumption (Wright, 2000). In the presence of the illiquid and irreversible nature of the assets of the poor, their vulnerability to random events or shocks (unforeseen circumstances) and their uncertainty about future prospects, cash or access to credit is much needed to smooth consumption. According to Meagher and Wilkinson (2001), Whiteford and McGrath (2000) and Mashigo and Schoeman (2011), access to credit is instrumental for development through the social empowerment role it plays by motivating income-generating activity, responsible behavior and economic independence, by taxing irresponsible behavior and by economizing on scarce resources to be allocated to the development of alternative institutions to insure against real and unmanageable market-related hardship. The formal financial sector, i.e., banks and other non-bank suppliers of credit, does not accommodate the need for credit by poor households because of the problem of imperfect information or informational uncertainty about them, and the irreducible uncertainty of their economic environment (Bernanke, 1980). Quantification of risk under these circumstances is difficult. This means that poor households are denied access to cash and are without sufficient hedges against the severe impact of relatively minor adverse events like temporary illness. They cannot rely on financial intermediation and, therefore, remain deprived of need-based credit.

In these circumstances, the traditional financial sector exemplified by village banks is very important in providing both savings and credit to poor households. Traditional institutions and instruments have a history of success and have, for some, time made access to credit possible for even the poorest of the poor. Savings and credit networks like stokvels (popularly used in the South African black townships and rural areas) have not received recognition or support commensurate with their current and potential contribution to improving the living standards of the economically marginalized majority (Baumann, 2001; Johnson and Rogaly, 1997; World Bank, 2002). 


\section{Conclusion and recommendations}

The aim of this study is to construct a conceptualized theoretical sound taxonomy of a social institution (i.e. a village bank) to substantiate its placement in the existing financial economic reality. Micro financial services encompass both savings and credit. The poor do not only need credit all the time but also savings facilities. In South Africa, micro-finance focuses on micro-credit only and disregards savings. This situation has marginalized the majority of South Africa's economically active poor and limited them from participating in the economy with marginal if no access at all to financial services. Ample evidence exists around the world that poor households have the propensity to save for emergencies through various informal savings schemes such as stokvels (Mashigo and Schoeman, 2011). These stokvels, according to Department of Agriculture, Forestry and Fisheries (2009), which are micro-savings as a strategy to enhance and sustain livelihoods is almost unknown if not recognized in South Africa despite wide recognition of its importance in the developing world. With this respect, the study argues that micro-finance needs a different kind of banking format in South Africa in order to recog- nize the micro-savings. For instance, a separate microfinance regulatory body can be established for institutionalizing the rural finance (the stokvels). Yunus (2003, p. 3) stated that "creation of separate legal framework, and a separate Micro-credit Regulatory Commission will be the result of the recognition". Furthermore, the regulatory body can play a pivotal role in developing appropriate policy for the recognition of micro-savings which can develop a dynamic rural financial sector in South Africa. To regulate micro-credit and rural finance, similar type of regulatory bodies are developed in many countries such as India, Pakistan, Philippines, Venezuela and Uganda (Yunus, 2003).

The study provided a large amount of South African village bank information from both historical and practical perspectives. Further, the study explored the concept and understanding of financial strategy of a village banking initiative in South Africa. Thus, a study that evaluates and documents village bank's financial strategy from an emerging economy's (like South Africa) perspective will significantly add a new dimension to village bank literature in an African context.

\section{References}

1. Baumann, T. (2001). Micro-finance and Poverty Alleviation in South Africa. Bay Research and Consultancy Services, Muizenberg, South Africa.

2. Calvin, B. and Coetzee, G. (2010). A Review of South African Micro-finance Sector 2009. Volume II - Background Papers: Section III - Market Supply. Centre for Micro-finance, University of Pretoria.

3. Coetzee, G. and Cross, C. (2003). The role of community banks in South Africa: Can it contribute to improve access to financial services for the poor? Working Paper 2002-03, Department of Agricultural Economics, Extension and Rural Development, University of Pretoria.

4. Cooperative Banks Development Agency and South African Reserve Bank. (2010/11). Combined Annual Report. Republic of South Africa.

5. Department of Agriculture, Forestry and Fisheries. (2009). Savings mobilisation strategy. Republic of South Africa, Directorate: Agriculture Development Finance.

6. Greene, A. and Berroth, A. (2002). The Kwa Khulisa Project Report: A study of how Creative Africa South can empower women through creativity and business. Wellensley: Wellensley College.

7. Hawkins, P. (2004). Second and Third Tier Banks: The solution to the savings challenge. Paper presented at the $4^{\text {th }}$ Annual Savings Symposium of the South African Saving Institutes, South African Reserve Bank, October 18.

8. Holcombe, S. (1995). Managing to Empower - The Grameen Bank's Experience of Poverty Alleviation. London: Zed Books.

9. Holt, S.L. (1994). The village bank methodology: Performance and prospects. In M. Otero and E. Rhyne (Eds.), The new world of micro-enterprise finance (pp. 156-204). London: IT Publications.

10. Jones, G.A. and Dallimore, A. (2009). Wither participatory banking? Experiences with village banks in South Africa, European Journal of Development Research, 21 (3), pp. 344-361.

11. Johnson, S. and Rogaly, B. (1997). Micro-finance and poverty reduction. Oxfam and Action Aid, London.

12. Mahmuda, I., Baskaran, A. and Pancholi, J. (2011). Financing Social Innovation: A Case Study of Micro Financing in Bangladesh, Institute for Economic Research on Innovation (IERI Working Paper 2011 0108), Tshwane University of Technology.

13. Mashigo, M.P. (2007). Extending credit to the low-income and poor households in South Africa: A system of principles. Doctoral thesis, Department of Economics and Econometrics, University of Johannesburg, Johannesburg.

14. Mashigo, M.P. and Schoeman, C.H. (2011). Micro-credit and the transforming of uncertainty since 1976: International lessons for South Africa, New Contree Journal, A Journal of Historical and Human Sciences for Southern Africa, 62, pp. 149-176.

15. Masina, L. (2013). Village Banking Empowers Poor Malawi Women. Voice of America News. May 9, 2013. Available at: http://www.voanews.com/articleprintview/1657768.html. (Accessed on 16 April, 2016).

16. Mathie, A. (2001). Including the excluded: Lessons learned from the poverty targeting strategies used by microfinance providers. The Coady International Institute, St Francis Xavier University. 
17. Mhango, H.K. (2015). Malawi Women Combat Poverty With Village Banking Initiative. Harambee Today: An Economic Discourse on Africa. May 7, 2015. Available at: http: harambeetoday.org/index.php/business/item/ 1575-malawi-women-combat-poverty-with-village-banking-initiative. (Accessed on: 16 April, 2016).

18. MRA, Government of Bangladesh (2008). List of Licensed MFI's, Dhaka: Government of Bangladesh. Available at: http://www.mra.gov.bd.

19. Napier, M. (2004). Savings, Mzansi and the changing landscape of access. Paper presented at the $4^{\text {th }}$ Annual Savings Symposium of the South African Savings Institutes, South African Reserve Bank, October 18.

20. Nigrini, M. (2001). Empowering poor rural villages through the provision of financial services by means of financial service cooperatives: A preliminary investigation into financial service cooperatives in South Africa. Paper presented at the International Jubilee Conference of the Economic Society of South Africa, Glenburn Lodge, September 13-14.

21. Satgar, V. (2003). Comparative study - Cooperative Banks and the Grameen Bank Model Co-operative and Policy Alternative Centre (COPAC). Parkwood, Johannesburg. South Africa.

22. Song, I. (2002). Collateral in Loan Classification and Provisioning. IMF Working Paper (WP/02/122). International Monetary Fund, Washington DC.

23. The Connection (2011). Enduring Success - CFIs' Indaba Presentation Summaries, The Connection, Issue 1, December, 2011.

24. Yunus, M. (2003). Some Suggestions on Legal Framework for Creating Micro-credit Banks. Grameen Bank, Dhaka, Bangladesh.

25. Whiteford, A. and McGrath, M. (2000). Distribution of income in South Africa. Human Science Research Council, South Africa.

26. World Bank (2002). Empowerment and poverty reduction. Washington: A Source book.

27. Www.rurdev.usda.gov. (2012). South African village banks receive World Bank Funding. Available at: http://www.rurdev.usda.gov/rbs/pub/mar00/south.htm. (Accessed on: 17 April, 2012). 